\title{
Reformulasi Politik Hukum Agraria
}

\author{
Margarito Kamis
}

\begin{abstract}
It is thought that the reformulation of the political agrarian is urgently, seriously and effectively managed. This reformulation is required firstly because the political changes, during the New Order regime with its 'developmental ideology', have ever destroyed the regulations of legal agrarian. Secondly, it is intended to enable the social welfare and human values to be appropriately constructed. The fundamental weaknesses of the Basic Principle of Agrarian Law and the chainging bases of the facets of material, social, economy, political and legal customs are also regarded as a part of the opinion of why the political reformulation of the legal agrarian must be enforced immediately. The main point of the reformulation is also concemed with the position of Legal societies and nations, and is should be framed on the equailty paradigm in law. Another point is that reconstruction of the regulations of authority and land ownership.
\end{abstract}

\section{Pendahuluan}

Kaji ulang terhadap politik hukum agraria sesungguhnya merupakan ide dasar tulisan ini. Ada dua alasan penting untuk sampai pada ide tersebut. Pertama, tanpa terasa UndangUndang No. 5 tahun 1960 tentang Ketentuan Dasar Pokok-Pokok Agraria (UUPA) telah memasuki usianya yang keempatpuluh tahun, sebuah usia undang-undang yang memungkinkan untuk dilakukan penilaian secara sungguh-sungguh terhadap substansi dan efektifitasnya. Kedua, bersamaan dengan usianya yang terbilang relatif panjang tersebut, pelaksanaannya secara empiris ternyata tidak lepas dari sederetan distorsi. Efek distortif pelaksanaan undang-undang ini, menimbulkan akibat yang demikian jauh. Setidak-tidaknya terhadap dua hal. Di sisi sosiologis, melemahkan wibawanya sendiri dan di sisi filosofis, memporakporandakan gagasan keadilan substantif yang hendak diwujudkan melalui undang-undang ini. Yang paling terpengaruh pada sisi kedua adalah masyarakat, mereka yang hendak diperbaiki nasibnya.

Politik hukum yang mengantarkan lahirnya UUPA berkisar pada dua tataran. Pertama, hendak mewujudkan suatu hukum agraria yang seragam (unifikatif) di seluruh wilayah Republik.ni sebagai sebuah konsekuensi logis dari eksistensi republik yang merdeka, dengan tertib hukum yang merdeka dan berkeadilan pula. Kedua, dimaksudkan untuk mewujudkan suatu bangunan masyarakat, khususnya petani, apakah petani penggarap, buruh tani dan lain sebagainya yang bermartabat. Melalui undang-undang ini para petani penggarap dan buruh tani dimungkinkan memperoleh akses 
terhadap sumberdaya ekonomi, dalam konteks ini yang dimaksudkan adalah tanah, sehingga distorsi pada struktur pemilikan dan penguasaan tanah dapat dieliminir. Harapannya adalah tercipta suatu masyarakat yang berkeadilan dan bermartabat.

Persoalannya adalah apakah kedua gagasan dasar tersebut terlaksana sepanjang sejarah pelaksanaan UUPA? Apakah tidak sebaliknya justru terjadi serangkaian distorsi yang tidak saja melemahkan wibawanya sendii, dan pada saat yang sama melemahkan posisi masyarakat? Tidakkah struktur penguasaan dan pemilikan tanah yang timpang sebelum diundangkannya undang-undang ini, kembali tejadi, seolah disengaja dan dibiarkan yang dikemas dengan berbagai dalih? Ataukah secara diam-diam, tetapi sistematis, berdasarkan interpretasi dan defenisinya sendiri, negara' demi pembangunan mereformulasi politik agraria yang secara inheren melekat pada UUPA untuk melicinkan jalannya pembangunan, di mana pembangunan telah muncul sebagai sebuah idiologi tersendiri dalam negara Orde Baru?

\section{Populisme atau Elitisme}

Kendati bukan satu-satunya, harus diakui, rakyat (baca: petani) merupakan salah satu fokus perhatian para perancang UUPA untuk diberdayakan. Strategi makro pemberdayaan petani versi UUPA dibangun di atas asumsi, tanah sebagai suatu sumber kehidupan paling berharga bagi petani. Melalui penguasaan dan pengusahaan tanah akan menimbulkan efek terhadap kesejahteraan mereka. Asumsi ini ternyata tidak terlampau signifikan, oleh karena setelah dilaksanakan program pendistribusian tanah, salah satu elemen dari landreform, yang tentu saja disertai dengan sertifikasi, muncul fenomena penjualan dijual, walaupun bukan merupakan fenomena umum. Tetapi persoalannya kemudian berkembang lebih kompleks seiring dengan digalakannya pembangunan selama Rezim Orde Baru. Sumardjono ${ }^{2}$ mengakui kompleksitas ini. Bagi Sumardjono, inilah yang membedakannya bila dibandingkan dengan keadaan pertanahan ketika UUPAdiundangkan, apalagi pada era PJP II.

Kebutuhan akan ketersediaan tanah berbanding lurus dengan intensitas pembangunan. Dalam konteks ini paradigma klasik yang sering digunakan yakni tidak ada satu bidang kehidupan yang tidak bersentuhan dengan tanah menjadi siginifikan. Yang menarik adalah seiring dengan kebutuhan akan tanah, muncul pula konfilik-konflik yang sangat eskalatif pada dua tataran; konflik antara petani - pemilik atau penggarap di satu pihak berhadapan dengan kaum pemodal, domestik maupun asing yang beraliansi strategis dan taktis dengan kekuasaan, bahkan

1Yang dimaksudkan dengan negara di sini adalah Rezim Orde Baru. Rezim Orde Baru adalah sebuah Rezim yang kuat. Lihat Juga Arief Budiman. 1991. Negara dan Pembangunan Studi Tentang Indonesia dan Korea Selatan. Ttp: Padi dan Kapas. Hlm. 59.

${ }^{2}$ Maria S.W. Sumardjono. 1994. “Dinamisasi Prinsip-prinsip UUPA Dalam Kerangka Umum Politik Pertanahan PJP II". Makalah Disampaikan Pada Seminar Nasional Permasalahan Dan Tantangan Politik Pertanahan Dalam PJP II. Kerjasama FH-UGM \& BPN, Yogyakarta. 29 Oktober 1994. HIm. 1. 
di sisi lain para petani hanus berhadapan secara langsung dengan pemerintah. Aliansi strategis antara kaum pemodal dengan kekuasaan akan membentuk hubungan simbiosis dan akhirnya menimbulkan suatu social polity yang mengandung ciri apa yang disebut Governance as privat enterprise. Dalam hal ini terjadilah suatu situasi yang bersifat self reinforcing antara jaringan kekuasaan politik dan jaringan kekuasaan ekonomi. Tersendatnya deregulasi pada bidang-bidang bisnis tertentu, perubahan status hutan lindung, upaya pihak swasta besar untuk merubah UUPA dan pengaruh pihak swasta besar dalam peruntukan tanah di kota-kota besar dan sekitarnya, dapat dijadikan contoh mengenai ini. $^{3}$

Distorsi yang memungkinkan terbangunnya hubungan simbiosis antara pemodal dan kekuasaan, yang karena kekentalan dan kekuatannya, meminggirkan rakyat, sesungguhnya dapat dilacak melalui tekad kekuasaan Orde Baru yang mempanglimakan ekonomi di awal-awal rezim ini. Pada tahun 1967 dikeluarkan UU No. 11 Tahun 1967 tentang Ketentuan Pokok Pertambangan. Bachriadi ${ }^{4}$ menyatakan ada kontradiksi (substansial - pen) antara UUPA dan UU ini. Pemilik tanah tidak dapat berbuat lain kecuali menyerahkan tanah yang dimiliki atau dikuasainya apabila tanah tersebut menjadi areal kuasa pertambangan. Keadaannya semakin runyam, oleh karena tidak jelas undang-undang mana yang mesti digunakan sebagai acuan dalam menyelesaikan masalah ini. Apalagi kedudukan kedua undang-undang tersebut setara, sehingga tidak begitu mudah untuk saling meniadakan. Pakta juga menunjukan betapa pada 1967 selain dikeluarkan Undang-Undang No.11 tahun 1967 tentang Pertambangan juga dikeluarkan Undang-Undang No. 1 Tahun Tentang Penanaman Modal Asing, setahun lebih dahulu dari Undang-Undang No. 6 tahun 1968 tentang Penanaman Modal Dalam Negeri. Pembeberan serangkaian Undang-Undang ini dimaksudkan untuk memberikan petunjuk betapa penghancuran karakter populis ${ }^{5}$ UUPA secara sistematis mulai dibenihkan, sehingga tipologi responsif ${ }^{6}$ yang juga disandangnya turut dicemari.

Melabeli UUPA dengan imbuhan populis dan responsif sama sekali tidak dapat diartikan bahwa secara substansial UUPA tidak mengidap kelemahan tertentu pada tingkat konseptualisasinya. Kelemahan ini memperbesar potensi penguasa untuk mempreteli melalui penggelembungan kebijakan yang bersifat ad

${ }^{3}$ Sritua Arief. 1997. Pembangunanisme dan Ekonomi Indonesia; Pemberdayaan Rakyat Dalam Arus Globalisasi. Jakarta: Zaman. Him. 53.

${ }^{4}$ Dianto Bachriadi. 1998. Merana Di Tengah Kelimpahan. Jakarta: EL.SAM. HIm. 106-108.

5Istilah pupulisme dimaksudkan untuk menggambarkan keberpihakan UUPA terhadap rakyat khususnya petani.

'Moh. Mahfud. MD. 1998. Politik Hukum Dilndonesia. Yogyakarta: LP3ES. Konsep responsif menunjukan pada terakomodasinya atau siginifikannya suatu undang-undang dengan perasaan keadilan, setidak-tidaknya dengan aspirasi masyarakat. hlm. 348. Tentang Konsep Hukum yang responsif, lihat juga Mulyana W. Kusuma dan Paul S. Baut. 1988. Hukum, Politik dan Perubahan Sosial. Jakarta: YLBHI. HIm. 21. 
hoc yang terantai hubungkan dengan intensitas perluasan sektor-sektor pembangunan yang bersentuhan langsung dengan tanah atau berdimensi keagrariaan. - Konsep hak menguasai negara, secara empiris telah disalahtafsirkan menjadi tanah dimiliki oleh negara.' Idiomnya ditangkap melalui penggunaan konsep tanah negara. Dalam artian konsep tanah negara telah dipandang sebagai elaborasi dari konsep tanah dikuasai oleh negara. Padahal konsep hak menguasai negara atas tanah hanya berakibat regulatoris, artinya wewenang pengaturan (regulasi) memang dimiliki oleh negara', bukan sebaliknya negara memiliki tanah. Wacana tanah negara, ternyata menjadi momok yang menakutkan bagi rakyat, ketika negara berkehendak, tentu karena pembangunan, menguasai sebidang tanah. Apalagi sejarah pertanahan sepanjang Orde Baru belum mencatat negara selalu menang ketika berhadapan dengan rakyatnya sendiri.

Konsep ini, kedepan memang layak untuk direformulasikan. Bagaimana mungkin hak ḿenguasai negara diposisikan, meminjam terminologi hukum adat, sebagai hak ulayat negara. Padahal hak ulayat itu sendiri murni merupakan terminologi hukum adat. Kelemahan kedua, dan karena itu menguatkan posisi negara dalam menguasai tanah, adalah konseptualisasi tanah adat. Kelemahan inj dapat ditandai dengan tidak jelasnya konsep masyarakat adat itu sendiri. Menunjuk eksistensi masyarakat adat sebagai prasyarat pengakuan dalam melakukan klaim areal tanah sebagai tanah adat atau ulayat, dalam ketidak-jelasan yang demikian telanjang di satu sisi dan di sisi lain dominannya negara dalam menejemen pertanahan, justru semakin merugikan masyarakat adat itu sendiri. Sebuah masyarakat hukum adat, karena eksistensi tradisionalnya berada dalam suatu teritori, maka mereka juga dengan sendirinya memiliki harta untuk kelangsungannya. Ketidak-jelasan konsep tersebut ternyata tidak serta merta membuat mereka tidak dapat mengekspresikan klaimnya terhadap hal yang dianggap sebagai miliknya. Lagi pula secara internasional, melalui konvensi International Labour Organization (ILO) 169 mengenai Bangsa Pribumi dan Masyarakat Adat di Negara-Negara Merdeka ${ }^{7}$ semakin mendapat perhatian yang sangat ménggembirakan. Perhatian ini tanpa sengaja tersinergi dengan kebangkitan kesadaraan tentang hak-hak mereka.

Kritik terhadap kelemahan konseptualisasi beberapa konsep yang pengaruhnya demikian mendasar terhadap implementasi UUPA, patut diragukan paradigma populisme atau kerakyatan yang disandang UUPA. Sangat bisa jadi paradigma itu lebih merupakan permainan politik kala itu, di mana konfigurasi politik rill, sesungguhnya berpusat pada Presiden Soekamo, yang menurut Lev ${ }^{8}$ dimungkinkan terlaksana di bawah payung politik demokrasi terpimpin. Wujudnya adalah rakyat diberi tempat yang seolah-olah dominan, tetapi pada

${ }^{7}$ Lihat Konvensi 169 Tentang Bangsa Pribumi dari Masyarakat Adat di Negara-negara Merdeka yang diadopsi oleh Intemational Labour Organisation (ILO) pada tanggal 27 Juli 1989.

DDaniel S. Lev. 1966. The Transition To Quided Democracy: Indonesian Politics, 1957-1959. Ithaca New York: Cornell Modern Indonesian Project: hlm. 59. 
saat yang sama Negara juga diberi tempat, yang sejauh ini secara riil dominasinya melebihi kepentingan rakyat, apapun dalih klaim yang diajukannya. Oleh karena tidak ada perbedaan yang sangat signifikan antara Rezim Orde Lama dan Rezim Orde Baru, maka tentu kelemahan konseptualisasi itu di satu sisi dengan pembangunan ekonomi sebagai panglima yang ditopang dengan stabilitas politik yang demikian hebat, maka Rezim Baru ini tinggal memetik dan melanjutkan keuntungan yang telah tersedia tersebut.

Apa yang hendak dikatakan dari uraian di atas adalah atmosfir, konfigurasi dan pergeseran politik ternyata mempengaruhi interpretasi rezim terhadap politik hukum agraria yang telah digariskan dalam UUPA. Bertolak dari interpretasi, lepas dari benar atau tidak, konsep politik hukum agraria pun dengan sendirinya mengalami pergeseran yang cukup siginifikan. Apalagi perbedaan dalam menafsirkan itu sendiri sangat dimungkinkan, disebabkan dan atau ditopang oleh ketidak-tuntasan konseptualisasi terhadap beberapa pranata yang sudah disebutkan di muka. Reproduksi kepincangan dalam struktur penguasaan dan pemilikan tanah sepanjang Rezim Orde Baru harus dibaca dalam kerangka ini, kerangka keiemahan dalam UUPA itu sendiri yang memungkinkan rezim ini mengembangkan politik hukum agraria sesuai interpretasi dan defenisinya sendiri di satu pihak dan di lain pihak perluasan sektor pembangunan yang bertaut langsung dengan tanah, mendorong rezim ini terus melanggengkan politik hukum agraria yang mengabdi pada pembangunan. Penggusuran penduduk yang telah menguasai tanah baik telah dilegitimasi, apalagi yang tak terlegitimasi - dalih negara untuk kảsus yang terakhir penguasaan secara liar, terlantarnya tanah yang secara formal diperuntukan untuk pengembangan kawasan industri atau perumahan (property) oleh kaum pemodal, yang ketika krisis moneter melanda indonesia, baru muncul ke permukaan betapa demikian luas tanah yang terlantar, disaksikan oleh demikian banyaknya penduduk yang tidak memiliki tanah merupakan fakta betapa pergeseran politik pertanahan yang terjadi sepanjang Rezim Orde Baru telah menimbulkan akibat, tidak saja permasalahan sosial tersendiri, akan tetapi secara filosofis telah menimbulkan ketidakadilan sosial yang demikian parah. Karena politik pertanahan sepanjang Rezim Orde Baru lebih berpihak kepada kaum pemodal (elit ekonomi) dibandingkan rakyat kebanyakan.

\section{Perubahan Basis Materiil}

Politik hukum pada dasamya merupakan artikulasi politis yang dikembangkan oleh negara terhadap aspirasi dan tuntutan masyarakat terhadap segala sesuatu yang berkaitan dengan kehidupannya. Aspirasi dan tuntutan-tuntutan itulah yang sesungguhnya merupakan basis materil dari politik hukum. Bila basis materil ini berubah, maka artikulasi politis untuk diformulasikan sebagai politik hukum berubah pula. Struktur penguasaan dan pemilikan tanah sejauh ini belum mengalami perubahan drastis. Fenomena terkonsentrasi penguasaan dan pemilikan tanah pada segelintir elit ekonomi berhadapan dengan rakyat kebanyakan masih bisa ditemui di mana-mana. Tetapi itu tidak berarti bahwa lingkungan strategis sebagai basis materiil dari sebuah undang-undang belum berubah. 
Sehingga reformulasinya merupakan sesuatu yang tidak dapat ditunda lagi. Perubahan suatu undang-undang menjadi signifikan ${ }^{9}$ manakala dua unsurnya bertemu pada satu titik singgung. Kedua unsur yang dimaksud adalah adanya keadaan baru yang timbul dan kesadaran akan perlunya perubahan pada masyarakat yang bersangkutan itu sendiri.

Lingkungan sosial dan sistem politik yang berlangsung sekarang, pada tataran tertentu sungguh-sungguh merupakan sesuatu yang memiliki perbedaan dibanding dengan lingkungan dan sistem politik Rezim Orde Baru. Kendati masih dapat diperdebatkan, akan tetapi apa yang berlangsung pada saat ini memperlihatkan nuansa demokrasi yang memadai. Hirarki yang sangat piramidal dalam struktur penguasaan dan pemilikan tanah, sebuah keadaan yang secara filosofis diyakini oleh Myren ${ }^{10}$ berpotensi menimbulkan reduksi terhadap cita-cita keadilan yang hendak dijamin dan diwujudkan melalui suatu perundang-undangan. Reduksi atas suatu keadilan akan membesar manakala hukum itu sendiri tidak dapat memainkan peran kontrol secara efektif. Efeknya bisa sangat luas, oleh karena hukum sebagai sebuah sistem diyakini oleh Friedman ${ }^{11}$ merupakan part of the system social control, walaupun sistem hukum itu bisa berfungsi secara sekunder atau sub-ordinasi dalam satu sistem sosial.
Rekonstruksi bangunan sosial dan politik yang sedang berlangsung yang ditandai dengan terbukanya partisipasi politik masyarakat melalui pembukaan saluran politik (partai politik), reformulasi fungsi dan peran beberapa institusi yang selama ini dipercaya memiliki andil dalam melemahkan peran hukum, termasuk hukum agraria, rekonstruksi peran supremasi hukum serta rekonstruksi otonomi daerah harus dilihat secara komprehensif untuk menandai betapa politik hukum agraria pada era ini mutlak untuk direformulasi. Masalahnya adalah bagaimana menentukan dan.menyepakati arah dan substansi reformulasi itu. Dalam konteks ini maka beberapa sudut pandang memerlukan perhatian khusus. Kasus reformasi agraria di Pakistan, yakni hambatan politik dari para tuan tanah (zamindari) yang secara konkrit mempengaruhi dengan berbagai cara agar reformasi agraria yang dilancarkan oleh pemerintah tidak meliputi tanah yang sudah dikuasainya ${ }^{12}$ patut diwaspadai. Sebab belum ada jaminan optimal bahwa kasus itu bukan tidak mungkin akan terjadi di Indonesia manakala reformasi agraria dilaksanakan.

Pertama, pemahaman tentang konsep agraria. Secara etimologis konsep agraria yang diintroduksi ke dalam UUPA dan wacanawacana yang berkembang telah dibatasi sedemikian rupa sehingga pengertiannya disamakan begitu saja dengan tanah. Padahal

פLihat Satjipto Rahardjo. 1986. Hukum dan Masyarakat. Angkasa Bandung. HIm. 101.

${ }^{10}$ Richard Myren. 1988. Law and Justice an Introduction. California: Brooks/Cole Publishing Company. HIm 20.

"Lawrence M. Friedman: 1984. "American Law. W.W. Norton \& Company." HIm. 9-10.

${ }^{12}$ A.A.G. Peter dan Koesriani Siswosoebroto. 1990. "Hukum dan Perkembangan Sosial." Buku Teks Sosiologi Hukum Buku III. Jakarta: Pustaka Sinar Harapan. HIm. 289. 
secara etimologis konsep agraria merupakan elaborasi lebih dari konsep acres dalam bahasa latin yang berarti, tidak hanya tanah melainkan apa yang ada di dalamnya, begitu air dan ruang angkasa. Urgensi untuk memahami konsep bertautan dengan konseptualisasi.secara formal dalam kerangka mereformulasi politik hukum agraria di masa datang. Memahami secara benar konsep, untuk menentukan pembatasan penggunaannya secara formal dalam undang-undang. Memang tidak mesti konsep latin itu ditransformasi secara apa adanya ke dalam undang-undang. Oleh karena itu, dibutuhkan kesepakatan untuk memilih, apakah misalnya menggunakan saja konsep agraria tetapi secara tegas dibatasi pada bidang pertanahan atau menggunakan konsep agraria tanpa pembatasan. Kesepakatan penggunanan konsep berhubungan dengan pengaturan bidang-bidang yang berkaitan, pertambangan dan kehutanan serta lingkungan misalnya. Jika menggunakan konsep agraria secara apa adanya, maka pengaturan tentang pertambangan, kehutanan serta lingkungan hidup misalnya tidak dapat dilepaskan dari undang-undang agraria, karena ia berkaitan satu sama dengan lainnya. Ini penting untuk menciptakan keharmonisan hukum baik secara vertikal maupun horisontal. Kontribusi sistem hukum adalah terintegrasi dan komprehensifnya politik hukum agraria sehingga dapat lebih memberikan jaminan kepastian. Kepastian hukum menjadi penting, bukan karena hukum itu sendiri, melainkan dalam sebuah negara hukum, kepastian hukum menjadi penting bagi masyarakat untuk merencanakan sesuatu perbuatan hukum tanpa takut dan cemas terhadap:arogansi negara yang tiba-tiba bisa mengintervensi kehidupan masyarakat. ${ }^{13}$

Kedua, konsep hak menguasai negara dan delegasi wewenang dalam pengaturannya. Sentralisasi dalam wewenang pengaturan kepada pemerintah pusat yang masih dianut dalam UUPA kini tampaknya layak untuk direformulasi. Tentu apabila otonomisasi daerah benar-benar hendak dilaksanakan. Jika demikian halnya, maka harus ada perubahan dalam konstruksi wewenang pengaturan di bidang pertanahan. Agar selaras dengan jiwa otonomi daerah, maka wewenang pengaturan di bidang pertanahan ini mestinya diotonomikan juga kepada pemerintah daerah otonom. Tidak ada jaminan memang bahwa dengan pengotonomian wewenang pengaturan di bidang pertanahan kepada pemerintah daerah otonom, serta merta dapat menghapuskan potensi kecenderungan orang pusat atau orang pada suatu daerah tertentu memiliki tanah di daerah lain sebagai miliknya. Lain masalahnyà apabila penguasaan itu dilakukan dalam kerangka investasi, tentu saja hak yang diberikan atau diperoleh bukan hak milik, melainkan hak guna usaha atau hak pakai. Sedikit banyaknya potensi itu. dapat dicegah melalui kualitas keterbukaan birokrasi di daerah otonom. Kualitas ini pun sangat tergantung pada kapabilitas demokratik yang berkembang di daerah.'

. Tidak kalah penting untuk direformulasi adalah konstruksi terhadap eksistensi masyarakat hukum adat yang berimplikasi pada pengakuan teritorinya (tanah adat).

13/bid., Him. 53-56. 
Konstruksinya harus dibuat lebih konkrit, bukan sebagaimana.Pasal 3 dan 5 UU.JPA saat ini yang hanya mengatur prinsip-prinsipnya saja. Bagaimanapun harus diakui bahwa kelemahan itu berkorelasi dengan munculnya konflikkonflik vertikal antara masyarakat adat dan negara ketika negara dengan berbagai alasan membutuhkan suatu areal tanah. Memberikan pengakuan dan pengaturan terhadap tanah masyarakat hukum adat sama sekali tidak dapat diartikan bahwa konsep tanah negara menjadi tidak relefan lagi untuk diatur. Ada dua hal yang patut diperhatikan dalam konteks ini. Pertama, adanya keseimbangan antara kedua konsep tersebut. Kedua, parameter normatifnya harus konkrit agar dapat dihindari tirani interpretasi baik dari negara maupun masyarakat hukum adat itu sendiri.

Di samping persoalan-persoalan di atas, Faqih' juga mencatat adanya persoalan lain. Persoalan yang dimaksud Faqih adalah batas pemilikan maksimum dan minimum (latifunsi dan minifundia). UUPA berikut UU No. 56 Tahun 1960 hanya mengatur batas maksimum dan minimum tanah pertanian. Di luar itu tidak ada pengaturan. Apakah politik ini masih relefan untuk dipertahankan atau malah sebaliknya perlu direfisi. Bagaimana dengan pemilikan tanah untuk perumahan di perkotaan. Tidakkah semestinya dilakukan pengaturan mengenai batas maksimum. Sehingga memungkinkan warga kota, khususnya yang berada di daerah-daerah slum untuk memperoleh akses dalam pemilikan tanah.
Sedikit tidaknya, pembatasan pemilikan maksimum atas tanah di perkotaan akan membantu mengecilkan konsentrasi tanah untuk perumahan pada segelintir elit perkotaan, konsentrasi mana merupakan salah satu penyebab melebarnya kesenjangan diperkotaan, khususnya di bidang perumahan.

\section{Konsistensi}

Sejauh ini belum ada tanda-tanda politik yang mengarah para reformulasi atau revisi UUPA. Kecuali beberapa waktu lalu ketika krisis ekonomi sedang berada di puncak kehidupan bernegara Republik ini, santer terdengar penanganan yang dilakukan secara parsial oleh pemerintah dalam bidang agraria. Parsialitas tersebut terindikasi melalui objek penanganannya. Bụkankah yang ditangani hanya sebatas tanah-tanah terlantar yang dikuasai oleh para pengembang (developer), yang tentu saja sempat teridentifikasi, berikut persertifikatan atas' tanah yang dikuasai puluhan tahun oleh masyarakat, tetapi sekali lagi hanya ditujukan pada tanah untuk perumahan, dan itupun hanya berlangsung di perkotaan. Di sisi lain hutan yang dikuasai dengan instrumen hak pengusahaan hutan, tentu yang belum dieksploitasi juga ditangani.

Penanganan yang dilakukan oleh masingmasing departemen, lepas dari ada tidak koordinasi, menunjukan betapa penanganan di biḍang agraria dilakukan secara parsial dan bersifat sangat ad hoc. Keadaan ini

${ }^{14}$ Mansour Fagih. "Reformamsi Agraria Era Globalisasi, Teori, Refleksi dan Aksi." Dalam Dianto Bachriadi, Erpan Faryadi \& Bonie Setyiawan. (eds). 1997. Reformasi Agraria. Jakarta: Lembaga Penerbit Fakultas Ekonomi Universitas Indonesia. Him. xxiv. 
sesungguhnya bisa dimengerti karena, lingkungan dan birokrasi yang dikembangkan sepanjang Rezim Orde Baru memang memungkinkan hal itu terjadi. Lagi pula reduksi terhadap politik hukum agraria sudah sedemikian parahnya. Yang menarik adalah belum ada tanda sedikitpun dari kabinet persatuan nasional pada saat ini untuk menyentuh bidang agraria (pertanahan), kecuali terjadi diskusi publik yang kritis terhadap eksistensi Badan Pertanahan Nasional. Apakah dihapus atau malah dipertahankan. Polemik ini menjadi semakin menarik manakala ditempatkan dalam kerangka politik hukum, khususnya politik agraria atau pertanahan. Menariknya adalah belum ada formulasi, jangankan tuntas dan komprehensif, tentang politik hukum agraria, tentu saja baru tiba-tiba urusan tanah hendak diotonomikan. Mengotonomikan atau tidak sesungguhnya bukan sebuah persoalan pelik. Dalam kerangka hukum persoalan itu menjadi pelik oleh karena tidak ada mainstream politik hukumnya. Harus dingat bahwa hingga saat ini, sentralisasi wewenang agraria yang diintroduksi dalam UUPA belum berubah. Jadi wewenang pengaturan dalam bidang pertanahan secara normatif masih dipegang oleh pemerintah pusat. Lagi pula UU No. 22 tahun 1999 tentang Otonomi Daerah tidak memberikan pengaturan terhadap masalah ini. Mungkin saja terkesampingkannya politik hukum agraria pada saat ini dilatarbelakangi oleh asumsi bahwa politik agraria tersubordinasi ke dalam politik otonomisasi yang berkembang pada saat ini. Walaupun demikian, justru saat inilah waktu yang tepat untuk membicarakan politik hukum agraria tersebut secara terintegrasi dengan berbagai perkembangan baru. Namun demikian, belum terdengar wacana, misalnya pada level parlemen tentang politik hukum agraria ini. Pengalaman pelaksanaan UUPA sepanjang Rezim Orde Baru mestinya dapat dijadikan rangsangan untuk memułai memperhatikan persoalan ini.

Ada hal yang mendasar dalam konteks ini yang berhubungan dengan proses pembuatan undang-undang. Penyiapan atau pembuatan suatu undang-undang yang terlampau tergesa-gesa, sesungguhnya tidak menjamin baiknya substansi dan struktur dari undangundang tersebut. Apalagi untuk merespons perasaan hukum masyarakat. Hal ini berkaitan serat dengan pembentukan atau penumbuhkembangkan budaya hukum, bukan saja masyarakat tetapi juga aparatur hukum, negara. Pemahaman dan artikulasi perasaan hukum masyarakat merupakan prasyarat pembentukan budaya hukum. Budaya hukum masyarakat, berkait dengan persepsi mereka atas nilai, lingkungan tempat mereka berada, gagasan-gagasan tentang moral, hak dan kewajiban dan lain sebagainya, ${ }^{15}$ maka variabilitasnya menjadi tak terhindarkan dan ini harus diartikulasi secara baik. Apa jadinya jika persoalan yang demikian bervariabel tersebut dipersepsi kemudian diformulasi secara tiba-tiba oleh perancang undangundanig. Interplay antara struktur (legal struc-

${ }^{15}$ Lihat lebih Lanjut Lawrence M. Friedman. Op. Cit. Hlm. 21-22. 
ture) dan budaya hukum (legal culture) sedikit banyak memberikan kontribusi terhadap efektifitas penegakan hukum. ${ }^{16}$ Konsistensi, dengan demikian menjadi mutlak untuk dipegang, jika hendak mewujudkan suatu politik hukum yang terintegrasi agar dapat melahirkan hukum yang berkarakter demoktratis, menjamin keadilan baik substantif maupun prosedural.

\section{Simpulan}

Kelemahan-kelemahan yang terkandung dalam UUPA, tanpa disadari telah mengakibatkan negara secara terencana dan sistematis, khusus sepanjang pelaksanaannya oleh Rezim Orde Baru mereduksi politik populisme yang menjadi mainstreamnya, digantikan dengan politik elitisme. Pengabaian hak milik seseorang atas tanah secara sistematis diintroduksi ke dalam undangundang pertambangan dan beberapa undang-undang lainnya. Keadaan ini semakin diperparah dengan terpanglimakannya ekonomi menurut defenisi dan artikulasi negara yang berakibat aturan-aturan bidang agraria selain dibuat secara ad hoc, juga secara sengaja diorientasikan idilogi pembangunan. Struktur penguasaan dan pemilikan tanah yang berbentuk piramidal, di mana kaum pemodal bersama-sama negara berada di puncak piramida berhadapan secara diametral dengan rakyat kebanyakan yang tidak kuasa menghadapinya. Aliansi kaum pemodal dan negara justru melanggengkan marjinalitas masyarakat kebanyakan.
Di samping kelemahan konseptualisasi hak dan posisi negara dalam pengaturan di bidang pertanahan, konstruksi masyarakat adat berikut hak atas tanah, karena normanya sangat abstrak atau tidak konkrit, tidak komprehensifnya pembatasan maksimum dan minimum, khususnya tentang tanah perkotaan berimplikasi logis terhadap tuntutan untuk kembali mereformulasi politik hukum agraria di masa datang. Reformulasi terhadap politik hukum agraria ini, menjadi signifikan disebabkan oleh beberapa faktor; di antaranya berubahnya lingkungan strategis dan ada kebutuhan baru. Perubahan lingkungan strategis ditandai dengan dibukanya partisipasi masyarakat, hukum hendak disupremasikan, dimana struktur, substansi dan kultur hukum juga akan mengalami rekonstruksi. Corak wewenang agraria sehubungan dengan politik otonomisasi akan sangat tergantung pada kesepakatan politik terhadap skenario makronya. Paradigma reformulasi politik hukum agraria, tidak mesti diubah secara radikal, oleh karena orientasi populis UUPA sesungguhnya masih amat relevan. Kecuali pada tataran konseptualisasi pengertian yang hendak digunakan dalam UU, misalnya apakah masih tetap menggunakan konsep agraria atau pertanahan. Jika konsep agraria tetap dipertahankan maka, mutlak untuk direformulasi beberapa ketentuan yang berkaitan dengannya, misalnya ketentuan di bidang pertambangan, kehutanan, lingkungan hidup berikut pengaturan mengenai pengairan. Sehingga konsistensi dan harmonisasi vertikal maupun horisontal bisa terpelihara.

${ }^{16}$ Daniel S. Lev. 1991. Hukum dan Politik Dilndonesia Kesinambungan dan Perubahan. Jakarta: LP3ES. HIm. 380-381. 
Jika reformulasi politik hukum agraria, tidak sekedar dilakukan sebagai pemanis politik bagi rakyat, maka terasa kinilah saatnya bagi parlemen untuk secara sungguh-sungguh membuka atau memulai wacana politik ke arah itu. Wacana politik yang melibatkan publik dan dilakukan secara sistematis, diyakini dapat merekam perasaan hukum masyarakat, suatu elemen budaya hukum.

\section{Daftar Pustaka}

Arief, Sritua. 1997. Pembangunanisme dan Ekonomi Indonesia. Pemberdayaan Rakyat dalam Arus Globalisasi. Jakarta: Zaman.

Bachriadi, Dianto. 1998. Merana Di Tengah Kelimpahan. Jakarta: ELSAM.

Budiman, Arief. 1991. Negara dan Pembangunan. Studi Tentang Indonesia dan Korea Selatan. Jakarta: Padi dan Kapas.

Fakih, Mansour. "Reformasi Agraria Era Globalisasi. Teori, Refleksi dan Aksi." Dalam Dianto Bachriadi, Erpan Faryadi \& Bonie Setiawan (Eds). 1997. Reformasi Agraria. FE.Ul. Jakarta.

Friedman, M L. 1984. "American Law". W.W. Norton Company.

Konvensi ILO 169. Mengenal Bangsa Pribumi dan Masyarakat Adat di Negara-negara Merdeka. Jakarta: ELSAM.
Kusuma, Mulyana\& Paul S. Baut. 1988. Hukum, Politik dan Perubahan Sosial. Jakarta: YLBHIl.

Lev, Daniel S. 1966. The Transition To Quided Democracy Indonesian Politics 1957-1959. California: Brooks/ Cole Publishing Company.

- - 1991. Hukum dan Politik. Kesinambungan dan Perubahan. Jakarta: LP3ES.

Mahfud, Moh MD. 1998. Politik Hukum Di Indonesia. Jakarta: LP3ES.

Myren, Rijchard. 1988. Law and Justice. An Introduction. California: Brook/Cole Publishing Company.

Peters,A.A.G \& Koesriani Siswosoebroto. 1990. Hukum dan Perkembangan Sosial. Buku Teks Sosiologi Hukum. Buku - III. Jakarta: Pustaka Sinar Harapan.

Rahardjo, Satjipto. 1986. Hukum dan Masyarakat. Bandung: Angkasa.

Sumardjono, Maria. S.W. 1994. "Dinamisasi Prinsip-Prinsip UUPA Dalam Kerangka Umum Politik Pertanahan Dalam PJP II." Makalah Disampaikan pada Seminar Nasional Permasalahan dan Tantangan Politik Pertanahan Dalam PJP /| Kerjasama FH-UGM \& BPN. pada tanggal 29 Oktober $1994 \mathrm{di}$. Yogyakarta. 